\title{
The conservation status of the Galápagos marine iguanas, Amblyrhynchus cristatus: a molecular perspective
}

\author{
Amy MacLeod*, Sebastian Steinfartz
}

\begin{abstract}
Traditionally, conservation management focuses efforts on taxonomic units. However, when the taxa used do not reflect biologically meaningful units, such methods should be reconsidered to avoid the loss of irreplaceable biodiversity. The Galápagos marine iguana (Amblyrhynchus cristatus) is listed as Vulnerable on the IUCN Red List of Threatened Species and is facing growing anthropogenic threats. Currently, management is based on a taxonomy which is questionable in the light of recent molecular data. As such, there is a danger that evolutionarily significant populations may be left vulnerable to extirpation. Herein, we apply molecular data to elucidate the population structure of this species across the Galápagos archipelago, and thus advise conservation management in the absence of a revised taxonomy. Applying a wealth of molecular data including 12 microsatellite loci and $1181 \mathrm{bp}$ of the mitochondrial control region in over 1200 individuals, we delineate distinct populations and prioritize their management. Bayesian population structure analysis revealed 10 distinct population clusters, which we propose as management units (MUs). All MUs are significantly differentiated, with one unit on San Cristóbal Island being particularly distinct in terms of both microsatellite loci and mitochondrial data. Based on estimates of the genetic effective population size $\left(\mathrm{N}_{\mathrm{e}}\right)$, we find the MUs comprised of populations occurring on Floreana, Española, Marchena, and San Cristóbal to be alarmingly small. In consideration of both $\mathrm{N}_{\mathrm{e}}$ and anthropogenic threats, we recommend that conservation practitioners focus efforts on Floreana and San Cristóbal islands, and argue that better census size estimates of populations are urgently needed.
\end{abstract}

Resumen. Tradicionalmente, la gestión de la conservación ha centrado sus esfuerzos en unidades taxonómicas. Sin embargo, cuando los taxones utilizados reflejan unidades que no son biológicamente significativas, tales métodos deben ser reconsiderados para evitar la pérdida irremplazable de la biodiversidad. La iguana marina de Galápagos (Amblyrhynchus cristatus) está catalogada como vulnerable en la Lista Roja de Especies Amenazadas de la UICN y se enfrenta a crecientes amenazas antropogénicas. Actualmente, el manejo de esta especie se basa en una taxonomía que es cuestionable a la luz de datos moleculares recientes. Como tal, existe el peligro de que aquellas poblaciones evolutivamente significativas puedan quedar vulnerables a la extinción. Bajo este contexto, aplicamos los datos moleculares para dilucidar la estructura de la población de esta especie en el archipiélago de Galápagos y así asesorar una correcta gestión de la conservación en ausencia de una taxonomía revisada. La aplicación de una gran cantidad de datos moleculares, incluyendo 12 loci microsatélites y 1181 pb de la región control mitocondrial en más de 1200 individuos, nos muestra poblaciones distintas que son prioritarias para su gestión. El análisis Bayesiano de la estructura poblacional reveló 10 grupos distintos de población, que proponemos como unidades de gestión (MUs). Todas las MUs se diferencian significativamente, y una unidad en la isla de San Cristóbal es particularmente distinta tanto en términos de loci microsatélites como de datos mitocondriales. En base a las estimaciones del tamaño genético efectivo de la población $\left(\mathrm{N}_{\mathrm{e}}\right)$, encontramos que las MUs compuestas por las poblaciones que aparecen en Floreana, Española, Marchena, y San Cristóbal son alarmantemente pequeñas. Considerando tanto el $\mathrm{N}_{\mathrm{e}}$ como las amenazas antropogénicas, recomendamos que los profesionales de la conservación centren sus esfuerzos en las islas de Floreana y San Cristóbal, y se defiende la necesidad urgente de establecer mejores estimaciones del tamaño del censo en las poblaciones de iguana marinas.

Keywords: conservation genetics, conservation management, effective population size, Galápagos archipelago, genetic management, IUCN Red List, management units, population biology.

\section{Introduction}

Zoological Institute, Department of Evolutionary Biology, Unit Molecular Ecology, Technische Universität Braunschweig, Mendelssohnstr. 4, 38106 Braunschweig, Germany

*Corresponding author; e-mail:

ms.amymacleod@gmail.com
A large and charismatic lizard, the endemic Galápagos marine iguana (Amblyrhynchus cristatus) is remarkable for a multitude of reasons. Their unique diets, life history, and apparent abilities to shrink by bone-mass absorption in unfavorable conditions (Wikelski and Thom, 
2000) all warrant much discussion. However, in some ways it is the fact that certain key aspects of their biology and evolutionary history have been overlooked that is particularly striking. To date, there is very little information regarding the geographic subdivision of A. cristatus, and as a result it is difficult to recognize and separately manage distinct populations. Management efforts presently focus on the seven subspecies described during the 19th and 20th centuries, and these form the basis of the status assessments on the International Union for Conservation of Nature (IUCN) Red List of Threatened Species (Nelson et al., 2004). In this way, the taxonomy of the Galápagos marine iguanas has a direct impact on its conservation management, as is common practice in the conservation of threatened species (Mace, 2004).

Galápagos marine iguana taxonomy, however, has not been reviewed for over half a century. Current systematics do not take into account information from molecular studies, though a striking mismatch exists between the current taxonomy and molecular data (fig. 1). Noteworthy disagreements include the two subspecies of Fernandina and Isabela, which in terms of microsatellite loci are very closely related and share several shallowly diverged population clusters. Conversely, the opposite situation exists on San Cristóbal and Santiago, where three well-differentiated populations (two on San Cristóbal and one on Santiago) are all represented by the same subspecies. Microsatellite data are generally considered unsuitable for taxonomic purposes, and it is certainly not the intention of this work to suggest otherwise. Instead, we use these data to illustrate the point that any management plan focusing on these taxonomic units may fail to adequately protect genetic diversity, which could in turn have serious consequences for the evolutionary potential of the species.

While molecular data for A. cristatus have been available for some time, they have not yet been applied to the issue of conservation management. Use of molecular methods is essential when considering protection of biodiversity at the most basic level recognized by the IUCN the genetic level (McNeely et al., 1990). Populations with a reduced genetic diversity may experience an enhanced extinction risk (Frankham, 2005) and as such, measures of genetic diversity (such as heterozygosity) are of great importance when considering the conservation status and future prospects of an endangered species (Frankham, 2010).

The description of genetic units, which can serve as management units (MUs) for conservation practitioners, can address this issue. Recognition of MUs facilitates conservation by providing distinct units that can be monitored and managed separately. They offer a means by which limited conservation resources can be directed to maximize the retention of genetic diversity across populations within a species. In a broader sense, MUs can be used to protect diversity below the species level, and can prove particularly useful when the direct observation of population boundaries is difficult. Use of genetic units for management has been recommended for the conservation of a variety of species, including marine turtles (Wallace et al., 2010), Komodo dragons (Ciofi et al., 1999), California sea lions (González-Suárez et al., 2009), various cetaceans (e.g., Oliveira et al., 2012; Cunha et al., 2014), and iguanas (Pasachnik et al., 2011). While MUs are generally applicable to many conservation issues, they can be particularly useful in cases, such as that of the Galápagos marine iguanas, when taxonomy is uncertain but prioritized protection is urgently needed.

\section{The contemporary status of the Galápagos marine iguanas}

Amblyrhynchus cristatus faces a number of anthropogenic threats, primarily from introduced invasive species (Kruuk and Snell, 1981; Cayot et al., 1994; Berger et al., 2007) and marine pollution (Wikelski et al., 2002). Feral animals on the Galápagos are a serious problem for many endemics, and invasives are found on at least 

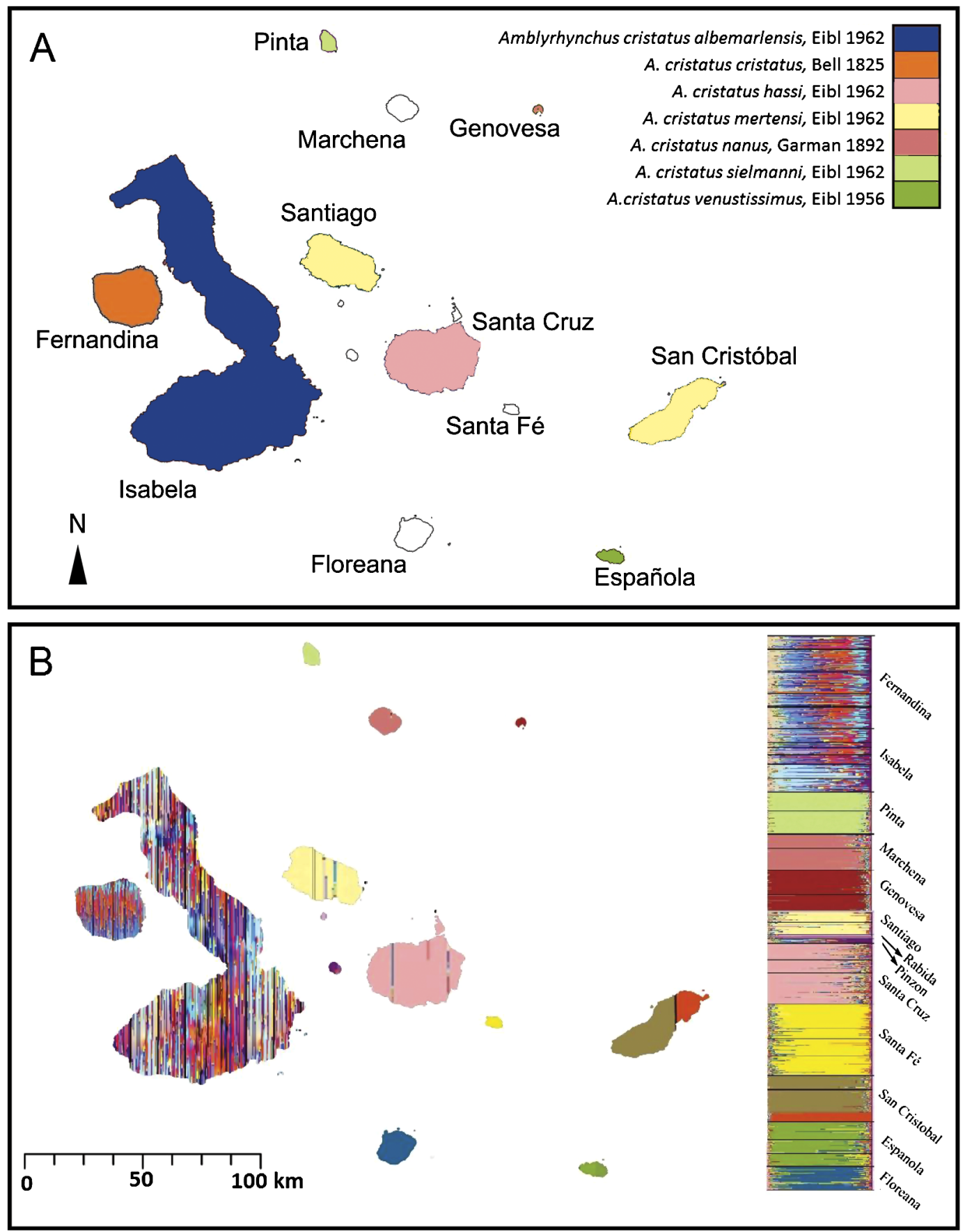

Figure 1. Comparison between current subspecies of Amblyrhynchus cristatus delineated on (A) morphology and (B) microsatellite data, adapted from work by Steinfartz et al. (2009), in the Galápagos Archipelago, Ecuador. Only islands represented in this study are labelled. Eibel is used here as abbreviated name for Eibl-Eibesfeldt. This figure is published in colour in the online version. 
five of the 13 main islands in the range of $A$. cristatus (Wikelski and Nelson, 2004). There is ample evidence to suggest that feral cats prey upon young iguanas (Konecny, 1983; Cayot et al., 1994), and dogs may pose a further threat to both adults and young (Kruuk and Snell, 1981). Though these feral animals are associated with human settlements, they also exist in remote locations, thus few areas can be considered pristine on affected islands. Eradication and control of invasive species represents a significant challenge, though examples of successful removal campaigns do exist (e.g., Campbell et al., 2004; Carrion et al., 2007; Aguilera et al., 2015).

Evidence of a new and serious threat to the Galápagos marine iguanas emerged in 2001, when unusually large numbers of dead iguanas were found close to the site of an oil tanker that had run aground. Long-term monitoring data revealed that the population on Santa Fé suffered $62 \%$ mortality as a result of a trace amount of oil leaked into the environment (Wikelski et al., 2002). It is thought that oil kills the gut endosymbionts that allow $A$. cristatus to digest algae, and thus the iguanas starve as a result of exposure to this contaminant (Wikelski et al., 2002). Marine pollution from a variety of sources is now considered an emergent threat in the Galápagos, and future risks for A. cristatus could potentially arise from a variety of pollutants associated with human activities, such as waste incineration and pesticide use (Alava et al., 2014).

Amblyrhynchus cristatus has evolved in the absence of adult predation, and populations are instead regulated by "famine and feast" events that occur as the result of sporadic but frequent climatic oscillations. These El Niño events, which bring higher sea surface temperatures, can result in population crashes of up to $90 \%$ through starvation (Laurie and Brown, 1990; Wikelski and Trillmich, 1997; Wikelski and Nelson, 2004). Though such crashes are dramatic, they are natural phenomena, and have occurred throughout the recent evolutionary history of the species. Therefore, in the absence of other compounding factors, these events should be of little concern for conservationists. However, climate modeling suggests that El Niño events could become increasingly severe with climate change (Timmermann et al., 1999). Furthermore, the ability of populations to withstand these stochastic events is likely related to population size, since small populations are the most vulnerable to local extinctions (Lande, 1998), thus populations depressed by anthropogenic threats may be at a higher risk of extirpation during severe El Niño events.

The conservation status of the Galápagos marine iguanas was last formally revised over 10 years ago (Wikelski and Nelson, 2004), though by the authors' own admission estimates on population census size numbers are "very rough". The largest populations are reported for Fernandina and Isabela islands, where up to 120000 and 40000 animals are estimated respectively. Of the 13 main islands on which $A$. cristatus are found, by far the smallest known population is that found on San Cristóbal Island, with an estimate of 50-400 individuals. This finding echoes concern voiced by earlier work (Rassmann, 1996a), reporting small populations and genetically depauperate animals on this island. However, we still lack fundamental data on the health and size of colonies on most islands due to the difficulty in accessing and monitoring these areas.

In addition to census size, the effective population size $\left(\mathrm{N}_{\mathrm{e}}\right)$ is a crucial parameter for conservationists (Luikart et al., 2010) because the adverse genetic consequences of a small population (reduced evolutionary potential, inbreeding depression, etc.) depend on its $\mathrm{N}_{\mathrm{e}}$, rather than its absolute number of individuals (Frankham et al., 2002). $\mathrm{N}_{\mathrm{e}}$ reflects the rate at which genetic diversity is lost following genetic drift, and is usually far lower than the actual (i.e., census) number of animals in the population. This is especially true for A. cristatus, where the lek mating system biases the genetic contribution of males in favor of the larger individuals (Wikelski et al., 1996), and thus $\mathrm{N}_{\mathrm{e}}$ is 
likely to represent only a small fraction of the census population size. $\mathrm{N}_{\mathrm{e}}$ in Galápagos marine iguanas has previously been estimated for some populations, for the purposes of measuring the impact of a severe El Niño event (Steinfartz et al., 2007). However, in this previous work the populations estimated were comprised of samples collected from geographically distinct sites or colonies, rather than distinct genetic units, diagnosable on a molecular basis. For conservation purposes, the $\mathrm{N}_{\mathrm{e}}$ of distinct MUs is a more useful measure. This consideration, taken together with the development of a new unbiased $\mathrm{N}_{\mathrm{e}}$ estimation method (Jorde and Ryman, 2007), justifies a reappraisal of these estimates.

\section{Aims}

Applying recent developments in computation and theory to molecular data gathered over the past 24 years, this work evaluates the status of Galápagos marine iguana populations found on 11 of the 13 main islands of the Galápagos, in order to facilitate effective conservation management. We aim to delineate genetically distinct populations on the basis of 12 highly variable microsatellite loci. The high levels of polymorphisms and rapid mutation rates of microsatellites make them particularly useful for measuring genetic diversity at the population level, and for investigations of ongoing processes occurring within and between populations of one species. We also apply sequence data from the highly variable mitochondrial control region (Hanley and Caccone, 2005), which can aid in the exploration of relationships between divergent populations within this species. The use of both types of data facilitates a deeper evaluation of the genetic variability, and allows us to consider two independent lines of evidence.

Little is known about the movements of $A$. cristatus (Rassmann, 1996a) and as such, the geographic boundaries of populations are unclear. For the purposes of this paper, we first identify populations by undertaking population structure analysis. Each significantly distinct and demographically separate genetic unit recovered is referred to thereafter as MU. We use MUs as they are commonly accepted (Fraser and Bernatchez, 2001; Mace, 2004; Frankham, 2010). Furthermore, prior work with these data (Steinfartz et al., 2009) indicates that they are not suited for the task of assessing whether populations meet evolutionary significant unit (ESU) requirements, e.g., reciprocal monophyly (Moritz, 1994). MUs can be viewed as populations that are sufficiently isolated such that their dynamics depend on local processes (e.g., birth and death rates) rather than immigration (Palsbøll et al., 2007). For each MU, genetic effective population size $\left(\mathrm{N}_{\mathrm{e}}\right)$ estimates, and various measures of genetic richness and interpopulation divergence are calculated in order to prioritize conservation management efforts. Finally, suggestions for management priorities and recommendations for future work of $A$. cristatus are made.

\section{Materials and methods}

Sampling

Material gathered for previous studies constitute the main body of data for this work (Rassmann, 1996a; Rassmann et al., 1997; Steinfartz et al., 2007, 2009). Existing samples were collected in two time periods: 1991-1993 and 2004. Previous research noted remarkable population differentiation on San Cristóbal Island (Rassmann, 1997; Steinfartz et al., 2009), but sampling in the northeast of the island (Punta Pitt), was comparatively low $(n=22)$. Therefore, we collected 345 new samples from this island between 2011 and 2014. Animals were captured using a pole fitted with a lasso loop and $<0.1 \mathrm{ml}$ of blood was collected from the caudal vein. Blood was stored in an SDS buffer (2\% SDS, $100 \mathrm{mM}$ Tris, $\mathrm{pH}$ adjusted to 7.5) and we extracted total genomic DNA with a standard chloroform extraction protocol, following the method described by Rassmann (1996a). During fieldwork, we clearly marked all sampled animals with non-toxic paint to avoid accidental resampling; these marks remained visible for the duration of the capturing activity in each field season, but wore off after a few weeks. To further ensure that repeated samples were not included, we used the 'multilocus match' option in GenAlEx (Peakall and Smouse, 2012) to identify any resampled animals on the basis of microsatellite loci. This was done on all 1600+ genotyped samples in our dataset and resulted in 37 samples being removed. 


\section{Amplification and preparation of mitochondrial dataset}

We generated mitochondrial $(\mathrm{mt})$ control region (CR; $1181 \mathrm{bp)}$ sequences for the 260 newly collected samples obtained in 2013 and 2014 using the primers and methods developed by Hanley and Caccone (2005), and added these sequences to an existing dataset $(n=1032)$ developed for previous studies (Rassmann et al., 1997; Steinfartz et al., 2009). We felt that 260 was a sufficiently large dataset for such purposes, and thus did not sequence the samples from 2011 and 2012.

\section{Amplification and preparation of microsatellite loci datasets}

We genotyped the 345 new samples at the 13 microsatellite loci described by Steinfartz and Caccone (2006), but one marker (E17) was rejected due to unreasonable failure rates in some populations. We scored alleles using GENEMARKER (v1.9, Softgenetics, State College, PA, USA) and analyzed the results with MICRO-CHECKER (Van Oosterhout et al., 2004) to check for systematic errors and null alleles. Figure 2 shows all sampling localities and table 1 gives sample sizes. We excluded any islands where sample size was below 20 . These were all very small islands (e.g., Rabida) located near larger (included) islands and none were found to be greatly distinct in earlier studies (Rassmann, 1996a; Rassmann et al., 1997; Steinfartz et al., 2009). Certain populations were strongly overrepresented with respect to others because of variation in density of animals and sampling effort. Since this can lead to artifacts within population structure analysis (Chikhi et al., 2010; Shringarpure and Xing, 2014), we standardized sample sizes by subsampling. All other analyses were undertaken using all available data, in order to better capture the full range of genetic variation within the archipelago (table 1).

\section{Population structure analysis}

Using a random pruning method, we developed a dataset where the sample size for each island was between 43 and 50. On islands where sampling was undertaken at more than one locality, samples from all areas collected in any time period were pooled, since previous analyses had not revealed any significant alteration in population structure within this time frame (Steinfartz et al., 2009). We treated data from San Cristóbal Island slightly differently, in recognition of the two strongly divergent populations described in previous studies (Rassmann et al., 1997; Steinfartz et al., 2009). In this case, we used two sets of $n=50$. Since these data were subsampled, we took the opportunity to exclude all individuals with missing data. In total, the 'pool' of all available samples represented 1359 individuals, from which we drew a subset of 590 samples across sites (table 1).

We used a model-based Bayesian clustering method (STRUCTURE v2.3.; Pritchard et al., 2000) to infer population structure from the 12 microsatellite loci. Parameters used were identical (with the exception of the $K$ range) to those of Steinfartz et al. (2009) and included 15 simulations for each $K$ from $K=1-20$, with a burn-in of 1 million followed by 100000 replicates. We interpreted the results following Evanno et al. (2005), as implemented in STRUCTURE HARVESTER (Earl and vonHoldt, 2012). We permuted data from replicated simulations using CLUMPP (Jakobsson and Rosenberg, 2007) and visualized it in DISTRUCT (Rosenberg, 2004). We first uncovered MUs by STRUCTURE analysis based on the subset of 590 samples, and then created two datasets for each MU with all available samples, one with the microsatellite loci data, and one with the mtDNA data (see table 1 for sample sizes used in each type of analysis).

\section{Delineation of MUs}

One commonly employed method to assess whether populations are demographically separate and can therefore be viewed as MUs is to test whether the assumption of panmixia between them can be rejected (Bentzen, 1998). This typically involves demonstrating significant levels of pairwise population divergence, usually on the basis of $F_{S T}$ or a related measure. However, the appropriateness of this method for MU delineation has been questioned (Palsbøll et al., 2007; Lowe and Allendorf, 2010) and obtaining an estimation of the level of dispersal between populations is recommended (Palsbøll et al., 2007) with $10 \%$ being the suggested threshold above which populations are demographically correlated (Hastings, 1993). In the present study, we delineated populations without the use of a priori data and then considered whether these populations met the criteria of being demographically separate using two approaches. First, to assess whether panmixia can be rejected we investigated levels of genetic differentiation by comparing pairwise fixation indices. For microsatellite loci, we used $\mathrm{R}_{\mathrm{ST}}$ (Slatkin, 1995). For the mtDNA, we used $\theta_{\mathrm{ST}}$, an analogue of $\mathrm{F}_{\mathrm{ST}}$. In both cases, we tested for significance using 10000 permutations in ARLEQUIN (Excoffier and Lischer, 2010). Secondly, we conducted assignment tests, which have been shown to perform well in providing estimates of dispersal rates (Berry et al., 2004) and can give a rough point-estimate of non-effective migration rates if the number of immigrants identified is divided by the sample size (Manel et al., 2005; Broquet and Petit, 2009). We used microsatellite loci data and utilized both the frequency-based method of Paetkau et al. (1997) in GenAlEx, and the partially Bayesian method of Rannala and Mountain (1997) in GENECLASS (Piry et al., 2004), in order to obtain estimates from two separate assignment methods. In GenAlEx, all individuals $(n=1359)$ were included to ascertain whether they assigned to their MU of origin (i.e., self-assigned) or another MU using the "leave one out" option. In GENECLASS, we utilized the exclusion method, where an individual is assigned to its population of origin only if the likelihood of it being assigned to all other populations is below a predetermined threshold; any individual failing to be assigned is therefore considered a possible migrant. For this we used all available samples and employed the simulation method of Paetkau et al. (2004), with 10000 simulated individuals and an alpha value of 0.01 , as recommended by Paetkau et al. (2004). We utilized $\mathrm{L}_{\mathrm{h}}$ as the test statistic, as is recommended in cases where there is the possibility that not all 

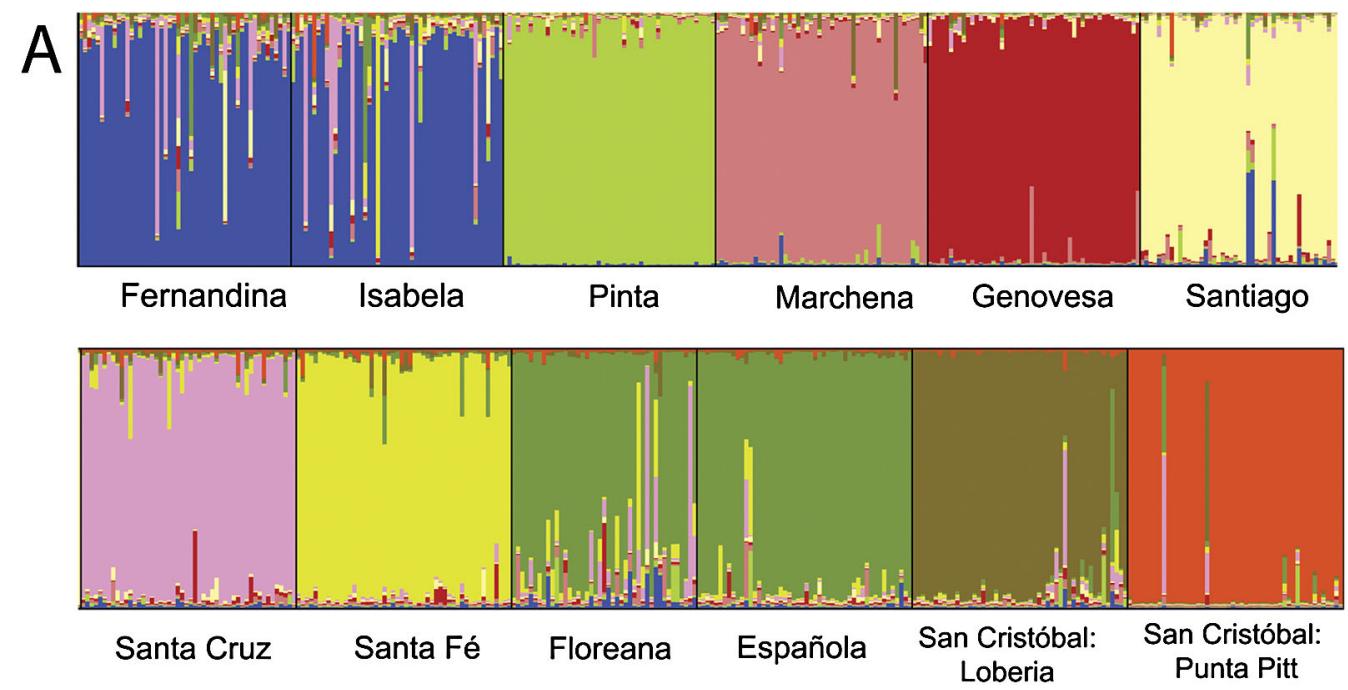

B
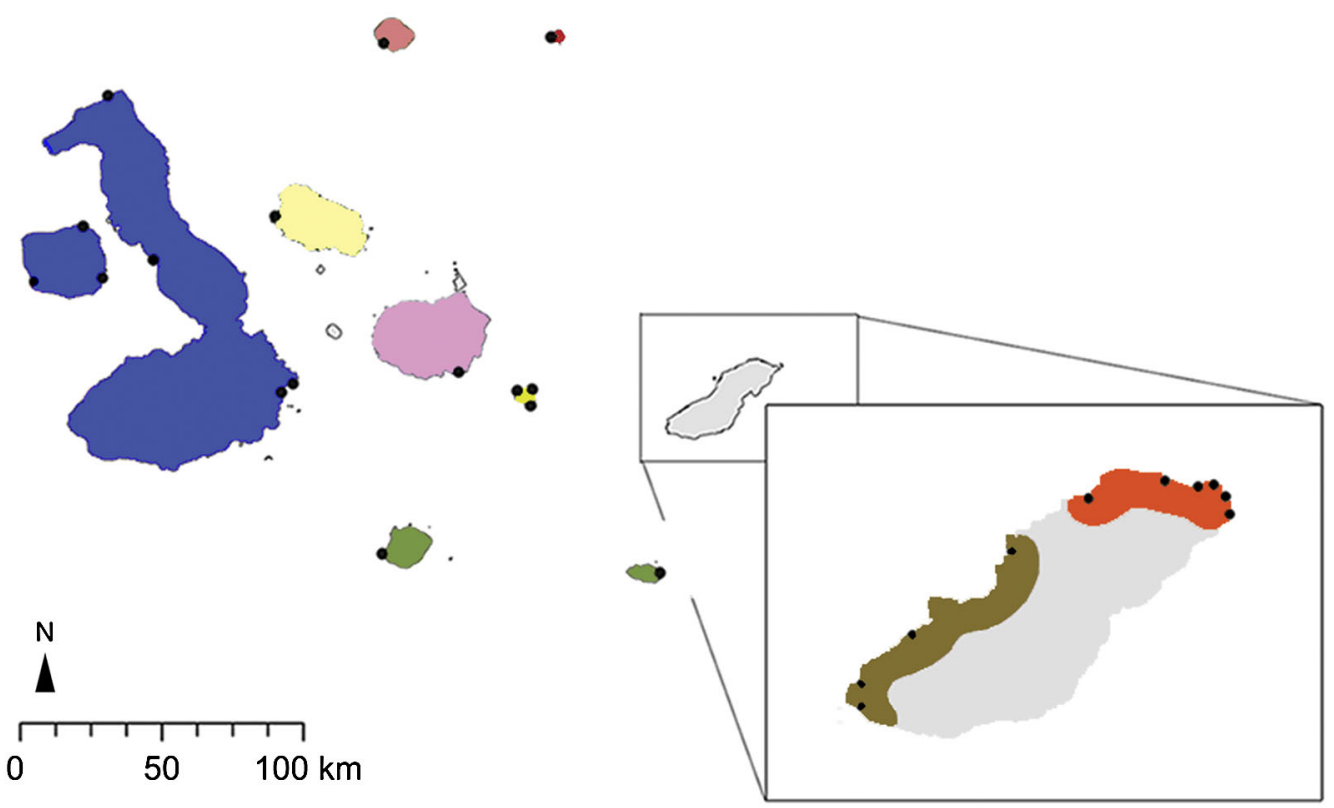

Figure 2. The outcome of population STRUCTURE analysis undertaken on Amblyrhynchus cristatus samples collected across the Galápagos archipelago, Ecuador, between 1991 and 2014, showing (A) genetic clusters found at each island on the basis of microsatellites, and (B) the recommended management units. Black dots demarcate sampling sites; sample sizes are given in table 1 . This figure is published in colour in the online version.

source populations are represented in the dataset (Paetkau et al., 2004). In addition, we tested for significant geographic structure within our mtDNA samples, by performing an analysis of molecular variance (AMOVA) in ARLEQUIN.

\section{Estimation of genetic effective population size}

A wealth of $\mathrm{N}_{\mathrm{e}}$ estimation methods is now available, each with its own advantages and caveats (Luikart et al., 1998). We chose to undertake $\mathrm{N}_{\mathrm{e}}$ estimation using a number of approaches that were applicable to our dataset, in order to 
Table 1. Sample sizes of Amblyrhynchus cristatus DNA collected across the Galápagos archipelago, Ecuador. Asterisks denote locations where new samples were collected between 2011 and 2014, all other samples are from 1991-1993 and 2004. Diversity and differentiation analysis for microsatellite tests included: assignment tests; $\mathrm{N}_{\mathrm{e}}$ estimation; genetic distance (RST); and genetic richness. Location codes are either new for this work, or are in keeping with Steinfartz et al. (2009) and are shown in fig. 2.

\begin{tabular}{|c|c|c|c|c|}
\hline \multirow[t]{3}{*}{ Island } & \multirow[t]{3}{*}{ Location code } & \multicolumn{3}{|c|}{ Marker and analysis type } \\
\hline & & \multicolumn{2}{|c|}{ Microsatellites } & \multirow{2}{*}{ 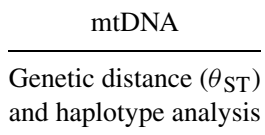 } \\
\hline & & $\begin{array}{l}\text { STRUCTURE } \\
\text { analysis }\end{array}$ & $\begin{array}{c}\text { Diversity and } \\
\text { differentiation analysis }\end{array}$ & \\
\hline \multirow{3}{*}{ Fernandina } & $\mathrm{FCH}$ & 0 & 0 & 20 \\
\hline & FPE & 30 & 85 & 86 \\
\hline & FPM & 20 & 69 & 73 \\
\hline \multirow[t]{3}{*}{ Isabela } & IPA & 28 & 54 & 27 \\
\hline & IBU & 7 & 13 & 15 \\
\hline & IWE/IBA & 15 & 22 & 28 \\
\hline Pinta & PCI & 50 & 87 & 94 \\
\hline Marchena & MAR & 50 & 66 & 78 \\
\hline Genovesa & GCA & 50 & 77 & 81 \\
\hline Santiago & SJB & 47 & 47 & 72 \\
\hline Santa Cruz & SCZ & 50 & 118 & 116 \\
\hline Santa Fé & SFN/SFX/SFN & 50 & 142 & 159 \\
\hline Floreana & FMO & 43 & 43 & 60 \\
\hline Española & $\mathrm{EPC}$ & 50 & 89 & 98 \\
\hline \multirow[t]{4}{*}{ San Cristóbal: Loberia } & SRL* & 30 & 90 & 78 \\
\hline & SRPA $*$ & 1 & 6 & 10 \\
\hline & SRIL/SRO $*$ & 15 & 40 & 11 \\
\hline & $\mathrm{SRCB} *$ & 4 & 20 & 15 \\
\hline \multirow[t]{9}{*}{ San Cristóbal: Punta Pitt } & SRBS* & 0 & 2 & 1 \\
\hline & SRG $*$ & 9 & 65 & 39 \\
\hline & $\mathrm{SRS} *$ & 5 & 40 & 9 \\
\hline & $\mathrm{SRPB} *$ & 6 & 62 & 52 \\
\hline & $\mathrm{SRIP} *$ & 22 & 36 & 49 \\
\hline & SRPC $*$ & 8 & 86 & 21 \\
\hline & Existing data & 512 & 1014 & 1032 \\
\hline & New data & 78 & 345 & 260 \\
\hline & Total & 590 & 1359 & 1292 \\
\hline
\end{tabular}

obtain several estimates for comparison. We calculated $\mathrm{N}_{\mathrm{e}}$ using one single-sample and two temporal methods. Single sample estimates were obtained using LDNE (Waples and Do, 2008), which is based on the principle that as population size decreases genetic drift within the parental generation results in non-random association among alleles at different loci. Other methods considered include the molecular coancestry method (Nomura, 2008) and the heterozygoteexcess method (Balloux, 2004). However, the literature suggests that both are capable of estimating $\mathrm{N}_{\mathrm{e}}$ only in very small populations (Luikart et al., 2010) and are thus unlikely to be useful for the present work. The temporal (also called moment-based or two-sample) methods used were TM3 (Berthier et al., 2002), a coalescent-based Bayesian method, and TEMPO-FS, the unbiased estimator of Jorde and Ryman (2007) which employs F-statistics and estimates $\mathrm{N}_{\mathrm{e}}$ based on changes in allele frequency resulting from genetic drift over successive generations. Both methods allow the inclusion of prior data: maximum census size $\left(\mathrm{N}_{\mathrm{c}}\right)$ in the case of TEMPO-FS, and maximum $\mathrm{N}_{\mathrm{e}}$ in the case of TM3. For these methods, we treated the two sample sets as generation zero and two, with the exception of San Cristóbal Island, where generations were zero and three, owing to the different sampling regimes. We used the upper limit of the $\mathrm{N}_{\mathrm{c}}$ given by Wikelski and Nelson (2004) as a prior for $\mathrm{N}_{\mathrm{c}}$, and since the ratio of $\mathrm{N}_{\mathrm{c}}$ to $\mathrm{N}_{\mathrm{e}}$ is unknown for A. cristatus, nominal values of $5 \%$ of the $\mathrm{N}_{\mathrm{c}}$ given was used as the prior for $\mathrm{N}_{\mathrm{e}}$. San Cristóbal Island was an exception, since the $\mathrm{N}_{\mathrm{c}}$ estimates are so low that these priors would be unworkably small. Additionally, from our recent work on this island we know that the population is likely to be far larger than the given upper estimate of 400 . Therefore, in this case, the prior $\mathrm{N}_{\mathrm{e}}$ used was 400 and $\mathrm{N}_{\mathrm{c}}$ was 800 . Both the LDNE and TEMPO-FS methods were implemented using NeESTIMATOR software (Do et al., 2014), and the TM3 method was employed in the older version (v1.3) of this software 
(Peel et al., 2004). For TEMPO-FS we used plan I, which does not assume sampling before reproduction since various life stages of A. cristatus are included in our dataset. We assumed random mating and excluded any alleles with a frequency below 0.01 .

Measures of population differentiation and genetic richness

For microsatellite loci data, we evaluated mean number of alleles per locus $(A)$, expected $\left(\mathrm{H}_{\mathrm{E}}\right)$, and observed $\left(\mathrm{H}_{\mathrm{O}}\right)$ heterozygosity values (Nei, 1987). For mtDNA data, we evaluated haplotypic (h) and nucleotide $(\pi)$ diversity (Nei, 1987), and number of haplotypes (\#h). We performed all calculations in ARLEQUIN v3.5. A haplotype network has previously been constructed on the basis of the same section of mitochondrial DNA used in this paper, and since we uncovered no new haplotypes, we did not construct a new network but refer instead to the previously published one (Steinfartz et al., 2009).

\section{Results}

Three hundred forty-five newly sampled individuals were successfully genotyped at 12 loci utilized by Steinfartz et al. (2009). Screening with MICRO-CHECKER confirmed the absence of null alleles and other common genotyping errors. We combined these with the existing dataset, removing samples with missing data, resulting in a pool of microsatellite data for 1359 individuals. All loci were heterozygous in all populations, with number of alleles across loci ranging from 10 to 32 . Mean number of alleles per locus across all populations was $10 \pm(\mathrm{SD}) 2$ alleles (range, 7-15 alleles) (table 2). Two hundred sixty individuals were successfully sequenced for $1181 \mathrm{bp}$ of mtDNA data; these were added to the existing dataset resulting in a total sample size of 1292 animals. From this, we uncovered a total of 102 haplotypes which have all been previously described by Steinfartz et al. (2009).

\section{Population structure}

STRUCTURE analysis strongly supported the division of our dataset into 10 genetic clusters (fig. 2). These clusters correspond to one cluster per island in most cases, although Isabela and Fernandina constitute a single cluster, as do Floreana and Española (fig. 2).

One further exception is San Cristóbal, where we obtained two clusters, confirming results of earlier studies (Steinfartz et al., 2009). In assignment tests in GenAlEx, 98\% of all individuals ( $n=1328$ of 1359) self-assigned to their cluster of origin across all populations (table 3), ranging from $93 \%$ in the Fernandina/Isabela cluster to $100 \%$ in the Marchena, Genovesa, Pinta, and Santa Fé clusters. The exclusion test in GENECLASS produced almost

Table 2. Genetic diversity values for the 10 management units uncovered during population structure analysis in $A m$ blyrhynchus cristatus from the Galápagos archipelago, Ecuador, based on analysis of $n$ individual Amblyrhynchus at 12 microsatellite loci and 1181 bp of the mitochondrial control region. Diversity measures are: (A) mean number of alleles per locus; $\left(\mathrm{H}_{\mathrm{O}}\right)$ mean observed heterozygosity; $\left(\mathrm{H}_{\mathrm{E}}\right)$ mean expected heterozygosity; (\#h) number of haplotypes; (h) haplotypic diversity; and $(\pi)$ nucleotide diversity; \pm standard deviations.

\begin{tabular}{|c|c|c|c|c|c|c|c|c|}
\hline \multirow[t]{2}{*}{ Population } & \multicolumn{4}{|c|}{ Microsatellite data } & \multicolumn{4}{|c|}{ Mitochondrial data } \\
\hline & $n$ & A & $\mathrm{H}_{\mathrm{O}}$ & $\mathrm{H}_{\mathrm{E}}$ & $n$ & \#h & $\mathrm{h}$ & $\pi$ \\
\hline Fernandina/Isabela & 243 & $15 \pm 5$ & $0.79 \pm 0.08$ & $0.85 \pm 0.05$ & 249 & 55 & $0.93 \pm 0.01$ & $0.0035 \pm 0.0019$ \\
\hline Pinta & 87 & $7 \pm 2$ & $0.64 \pm 0.15$ & $0.65 \pm 0.13$ & 94 & 6 & $0.43 \pm 0.06$ & $0.0012 \pm 0.0008$ \\
\hline Marchena & 66 & $9 \pm 3$ & $0.80 \pm 0.06$ & $0.80 \pm 0.05$ & 78 & 4 & $0.56 \pm 0.05$ & $0.0030 \pm 0.0017$ \\
\hline Genovesa & 77 & $8 \pm 2$ & $0.72 \pm 0.09$ & $0.71 \pm 0.07$ & 81 & 5 & $0.57 \pm 0.05$ & $0.0030 \pm 0.0017$ \\
\hline Santiago & 47 & $9 \pm 3$ & $0.78 \pm 0.07$ & $0.79 \pm 0.07$ & 72 & 3 & $0.55 \pm 0.02$ & $0.0060 \pm 0.0032$ \\
\hline Santa Cruz & 118 & $11 \pm 5$ & $0.82 \pm 0.07$ & $0.84 \pm 0.06$ & 116 & 2 & $0.02 \pm 0.02$ & $0.0001 \pm 0.0001$ \\
\hline Santa Fé & 142 & $10 \pm 4$ & $0.76 \pm 0.12$ & $0.76 \pm 0.12$ & 159 & 6 & $0.79 \pm 0.01$ & $0.0022 \pm 0.0013$ \\
\hline Floreana/Española & 132 & $12 \pm 5$ & $0.81 \pm 0.08$ & $0.81 \pm 0.08$ & 158 & 17 & $0.83 \pm 0.02$ & $0.0036 \pm 0.0020$ \\
\hline San Cristóbal: Loberia & 156 & $9 \pm 3$ & $0.74 \pm 0.09$ & $0.76 \pm 0.08$ & 114 & 3 & $0.66 \pm 0.02$ & $0.0022 \pm 0.0013$ \\
\hline San Cristóbal: Punta Pitt & 291 & $7 \pm 3$ & $0.63 \pm 0.13$ & $0.64 \pm 0.13$ & 171 & 1 & $0.00 \pm 0.00$ & $0.0000 \pm 0.0000$ \\
\hline Total/Mean & 1359 & $10 \pm 2$ & $0.75 \pm 0.07$ & $0.76 \pm 0.07$ & 1292 & 10 & $0.53 \pm 0.31$ & $0.0025 \pm 0.0018$ \\
\hline
\end{tabular}


Table 3. Results of assignment tests showing number of self- and non-self-assigned individuals per cluster of Amblyrhynchus cristatus from the Galápagos archipelago, Ecuador.

\begin{tabular}{|c|c|c|c|c|c|c|c|c|c|c|c|c|}
\hline \multirow[t]{2}{*}{ MU } & \multirow[b]{2}{*}{ 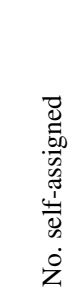 } & \multirow[b]{2}{*}{ 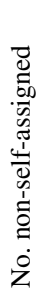 } & \multirow[b]{2}{*}{ 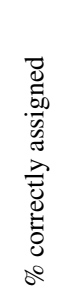 } & \multirow[b]{2}{*}{ 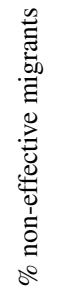 } & \multicolumn{8}{|c|}{ Assignment of individuals to other MUs } \\
\hline & & & & & 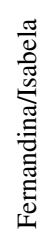 & $\stackrel{\Xi}{\Xi}$ & 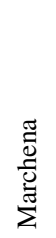 & 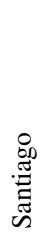 & $\begin{array}{l}\tilde{J} \\
\tilde{U} \\
\widetilde{\Xi} \\
\tilde{J} \\
\tilde{n}\end{array}$ & 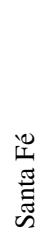 & 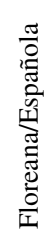 & 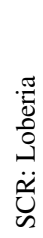 \\
\hline Fernandina/Isabela & 227 & 16 & 93 & 7 & & 1 & 2 & 5 & 6 & & 1 & 1 \\
\hline Pinta & 87 & 0 & 100 & 0 & & & & & & & & \\
\hline Marchena & 66 & 0 & 100 & 0 & & & & & & & & \\
\hline Genovesa & 77 & 0 & 100 & 0 & & & & & & & & \\
\hline Santiago & 46 & 1 & 98 & 2 & & & & & & & 1 & \\
\hline Santa Cruz & 117 & 1 & 99 & 1 & & & & & & & 1 & \\
\hline Santa Fé & 142 & 0 & 100 & 0 & & & & & & & & \\
\hline Floreana/Española & 124 & 8 & 94 & 6 & 1 & & & & 1 & 6 & & \\
\hline SCR: Loberia & 154 & 2 & 99 & 1 & & & & & 2 & & & \\
\hline SCR: Punta Pitt & 287 & 4 & 99 & 1 & & & & & & & 1 & 3 \\
\hline Total & 1328 & 31 & 98 & 2 & & & & & & & & \\
\hline
\end{tabular}

identical results, assigning $98 \%(n=1329$ of 1359) of individuals to their source population. The number of non-effective migrants per population ranged from zero in Genovesa, Marchena, Pinta, and Santa Fé to seven in the Fernandina/Isabela MU.

\section{Results of $N_{e}$ estimation}

Both the LDNE and TM3 failed to produce $\mathrm{N}_{\mathrm{e}}$ estimates for most populations, giving unreasonably large confidence intervals (CIs) which reached infinity in many cases (table 4). However, we obtained estimates for all populations except Santiago using the TEMPO-FS method. In the case of Santiago, this failure may be due to the small sample size available for both sampling intervals $(n=20$ in 1991-93 and 27 in 2004); given the small $\mathrm{N}_{\mathrm{c}}$ estimated for this population (Wikelski and Nelson, 2004) it is unlikely that the population is too large to estimate. Most MUs are well below the $\mathrm{N}_{\mathrm{e}}=$ 1000 threshold, which is thought necessary to maintain evolutionary potential (Frankham et al., 2014); including Pinta (254, CI: 175-349), Santa Cruz (167, CI: 126-214), Santa Fé (270, CI: 200-350), Floreana/Española (209, CI: 160-
265), and both San Cristóbal populations (Loberia 84, CI: 61-111; Punta Pitt 75, CI: 49-106).

\section{Measures of genetic richness and differentiation}

All clusters recovered in the STRUCTURE analysis were significantly differentiated from one another in terms of both mtDNA and microsatellite data (table 5). We found the highest $\mathrm{R}_{\mathrm{ST}}$ values when comparing Punta Pitt and Pinta to other MUs. For the mtDNA, Punta Pitt $\theta_{\mathrm{ST}}$ values are particularly high, as are those for Santa Cruz. Mitochondrial DNA variation revealed high levels of structure across the archipelago (table 6; $P<0.0001$ ), with the majority of variation $(70 \%)$ occurring between, rather than within, MUs.

In terms of microsatellite loci, genetic diversity measures demonstrated marked variation across the archipelago (table 2), with significant differences between mean number of alleles per population in both $\mathrm{H}_{\mathrm{O}}$ and $\mathrm{H}_{\mathrm{E}}$ (one-way ANOVA; $P<0.001)$. The Fernandina/Isabela, Santa Fé, and Santiago MUs show consistently high levels of heterozygosity and genetic richness across several measures, whereas the Punta 
Table 4. Results of $\mathrm{N}_{\mathrm{e}}$ estimation in management units of Amblyrhynchus cristatus from the Galápagos archipelago, Ecuador, based on three methods. No estimates are given in cases where the confidence intervals reached infinity or exceeded the prior values. Priors are based on published census size estimates (Wikelski and Nelson, 2004).

\begin{tabular}{|c|c|c|c|c|c|c|c|c|c|}
\hline \multirow[t]{3}{*}{ Management Unit } & \multirow[t]{3}{*}{ Prior $\mathrm{N}_{\mathrm{e}} / \mathrm{N}_{\mathrm{c}}$} & \multirow{3}{*}{$\begin{array}{l}\text { Sampling } \\
\text { interval }\end{array}$} & \multirow[t]{3}{*}{$n$} & \multirow{2}{*}{\multicolumn{2}{|c|}{$\begin{array}{c}\text { Single sample } \\
\text { LDNE }\end{array}$}} & \multicolumn{4}{|c|}{ Temporal } \\
\hline & & & & & & \multicolumn{2}{|c|}{ TEMPO-FS } & \multicolumn{2}{|c|}{ TM3 } \\
\hline & & & & $\mathrm{N}_{\mathrm{e}}$ & $\mathrm{CI}$ & $\mathrm{N}_{\mathrm{e}}$ & $\mathrm{CI}$ & $\mathrm{N}_{\mathrm{e}}$ & $\mathrm{CI}$ \\
\hline Fernandina/Isabela & $8000 / 160000$ & $\begin{array}{l}1991 / 93 \\
2004\end{array}$ & $\begin{array}{r}97 \\
146\end{array}$ & & & 2388 & $1858-2984$ & & \\
\hline Santiago & $200 / 4000$ & $\begin{array}{l}1991 / 93 \\
2004\end{array}$ & $\begin{array}{l}20 \\
27\end{array}$ & 87 & $53-210$ & & & & \\
\hline Pinta & $300 / 6000$ & $\begin{array}{l}1991 / 93 \\
2004\end{array}$ & $\begin{array}{l}38 \\
49\end{array}$ & & & 254 & $175-349$ & & \\
\hline Genovesa & $750 / 15000$ & $\begin{array}{l}1991 / 93 \\
2004\end{array}$ & $\begin{array}{l}43 \\
34\end{array}$ & & & 964 & $672-1309$ & & \\
\hline Marchena & $500 / 10000$ & $\begin{array}{l}1991 / 93 \\
2004\end{array}$ & $\begin{array}{l}27 \\
39\end{array}$ & 148 & $85-462$ & 70 & $51-92$ & 53 & $33-129$ \\
\hline Santa Cruz & $650 / 13000$ & $\begin{array}{l}1991 / 93 \\
2004\end{array}$ & $\begin{array}{l}35 \\
83\end{array}$ & & & 167 & $126-214$ & & \\
\hline Santa Fé & $800 / 16000$ & $\begin{array}{l}1991 / 93 \\
2004\end{array}$ & $\begin{array}{l}77 \\
65\end{array}$ & 485 & $253-3218$ & 270 & $200-350$ & & \\
\hline Floreana/Española & $1850 / 37000$ & $\begin{array}{l}1991 / 93 \\
2004\end{array}$ & $\begin{array}{l}49 \\
83\end{array}$ & $\begin{array}{l}286 \\
201\end{array}$ & $\begin{array}{l}161-1049 \\
155-278\end{array}$ & 209 & $160-265$ & & \\
\hline San Cristóbal: Loberia & $225 / 400$ & $\begin{array}{l}1991 / 93 \\
2012-14\end{array}$ & $\begin{array}{r}31 \\
125\end{array}$ & $\begin{array}{l}91 \\
71\end{array}$ & $\begin{array}{l}52-261 \\
62-81\end{array}$ & 84 & $61-111$ & 102 & $64-173$ \\
\hline San Cristóbal: Punta Pitt & $225 / 400$ & $\begin{array}{l}1991 / 93 \\
2011-14\end{array}$ & $\begin{array}{r}22 \\
269\end{array}$ & $\begin{array}{l}21 \\
37\end{array}$ & $\begin{array}{l}12-54 \\
32-43\end{array}$ & 75 & 49-106 & 147 & $74-400$ \\
\hline
\end{tabular}

Table 5. Population pairwise $\theta_{\mathrm{ST}}$ values from mitochondrial data (above diagonal) and $\mathrm{R}_{\mathrm{ST}}$ values from microsatellite data (below diagonal) between the 10 populations as identified in the population structure analysis of Amblyrhynchus cristatus from the Galápagos archipelago, Ecuador. SCR: San Cristóbal Island. All comparisons were highly significant $(P<0.0001)$.

\begin{tabular}{|c|c|c|c|c|c|c|c|c|c|c|}
\hline & 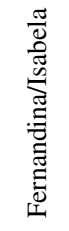 & $\underset{\mathscr{a}}{\stackrel{\Xi}{\Xi}}$ & $\begin{array}{l}\frac{\pi}{ \pm} \\
\frac{\pi}{0} \\
\frac{\pi}{\Sigma}\end{array}$ & $\begin{array}{l}\text { गू } \\
0 \\
0 \\
0 \\
0 \\
0\end{array}$ & 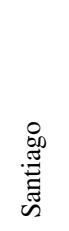 & 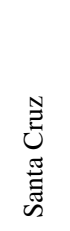 & 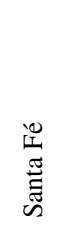 & 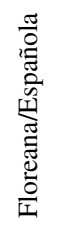 & 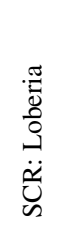 & 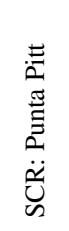 \\
\hline Fernandina/Isabela & & 0.43 & 0.33 & 0.33 & 0.51 & 0.75 & 0.70 & 0.61 & 0.66 & 0.81 \\
\hline Pinta & 0.15 & & 0.12 & 0.27 & 0.59 & 0.94 & 0.79 & 0.70 & 0.83 & 0.96 \\
\hline Marchena & 0.09 & 0.18 & & 0.16 & 0.44 & 0.87 & 0.72 & 0.62 & 0.70 & 0.92 \\
\hline Genovesa & 0.13 & 0.29 & 0.12 & & 0.44 & 0.86 & 0.71 & 0.61 & 0.72 & 0.91 \\
\hline Santiago & 0.07 & 0.19 & 0.10 & 0.13 & & 0.65 & 0.63 & 0.47 & 0.91 & 1.0 \\
\hline Santa Cruz & 0.05 & 0.20 & 0.08 & 0.12 & 0.08 & & 0.55 & 0.40 & 0.89 & 0.96 \\
\hline Santa Fé & 0.10 & 0.23 & 0.11 & 0.16 & 0.14 & 0.09 & & 0.21 & 0.83 & 0.86 \\
\hline Floreana/Española & 0.07 & 0.18 & 0.09 & 0.13 & 0.08 & 0.07 & 0.07 & & 0.75 & 0.77 \\
\hline SCR: Loberia & 0.09 & 0.24 & 0.11 & 0.15 & 0.12 & 0.08 & 0.09 & 0.09 & & 0.93 \\
\hline SCR: Punta Pitt & 0.17 & 0.40 & 0.23 & 0.32 & 0.28 & 0.17 & 0.19 & 0.20 & 0.15 & \\
\hline
\end{tabular}

Pitt and Pinta MUs were comparatively low. Both of these MUs had highly significant lower than expected heterozygosity than the Santiago and Fernandina/Isabela MUs $(P<0.001)$, and significantly lower values than Santa Fé $(P=$ $0.01)$ and Marchena $(P=0.04)$.
Additionally, Genovesa has significantly lower $\mathrm{H}_{\mathrm{E}}$ than either Fernandina/Isabela $(P=$ $0.01)$ or Floreana/Española $(P=0.02)$. In terms of mtDNA, the greatest haplotypic diversity ( $h$; table 2) occurs in the Fernandina/Isabela $(0.93 \pm(\mathrm{SD})$ 0.01) and Floreana/Española MUs 
Table 6. Results of AMOVA comparisons between populations of Amblyrhynchus cristatus from the Galápagos archipelago, Ecuador, based on 1181 bp of mitochondrial data.

\begin{tabular}{lrcc}
\hline Source of variation & \multicolumn{3}{c}{ Mitochondrial DNA sequence } \\
\cline { 2 - 4 } & d.f. & $\begin{array}{c}\text { Variance } \\
\text { components }\end{array}$ & \% Variation \\
\hline Among groups & 9 & 3.5 & 70 \\
$\begin{array}{c}\text { Among populations } \\
\text { within groups }\end{array}$ & 28 & 0.2 & 4 \\
\begin{tabular}{l} 
Within populations \\
\hline
\end{tabular} & 1254 & 1.3 & 26 \\
\hline
\end{tabular}

$(0.83 \pm 0.02)$, and is lowest for Santa Cruz $(0.02 \pm 0.02)$ and Punta Pitt $(0.00 \pm 0.00)$. Pinta also has relatively low haplotypic diversity $(0.43 \pm 0.06)$, but the difference is less pronounced than for microsatellite loci. For nuclear diversity $(\pi)$, Santiago $(0.0060 \pm 0.0032)$, Floreana/Española $(0.0036 \pm 0.0020)$ and Fernandina/Isabela $(0.0035 \pm 0.0019)$ demonstrate the highest values, with Santa Cruz (0.0001 \pm $0.0001)$ and Punta Pitt $(0.0000 \pm 0.0000)$ again being the lowest. All individuals from the Punta Pitt MU harbor only one mtDNA haplotype, which is also private to this MU. On Santa Cruz, the lack of mtDNA diversity was similar; 115 of 116 individuals have the same haplotype, and it is probable that the remaining animal is a migrant from another island, as indicated by the results of the assignment test (table 3 ).

\section{Discussion}

\section{Population structuring on the archipelago}

Population structure analysis strongly supported the delineation of the 11 sampled islands into 10 significantly differentiated population clusters (fig. 2). The high level of self-assignment confirms the strength of these clusters (Manel et al., 2005). In addition, the number of non-effective migrants estimated for each population is under the $10 \%$ threshold, indicating demographic separation (Hastings, 1993). Since these are noneffective migrants, their reproductive contribution is not assured and thus the actual dispersal rate is likely to be far lower. Given the large number of samples and loci utilized, these tests can be expected to have sufficient power to identify migrants (Paetkau et al., 2004). All 10 clusters should be considered distinct MUs.

These MUs, obtained with no a priori information, correspond remarkably well with island populations of the Galápagos marine iguanas, and make intuitive sense when interpreted with the geography of the archipelago and the age of the islands, which in general increases as you move eastwards across the archipelago (Geist et al., 2014). The two joint island clusters of Fernandina/Isabela and Española/Floreana appear reasonable given the proximity and relatively similar ages of the islands (Geist et al., 2014). This could also be due to progressive colonization of $A$. cristatus from older to younger islands, as this is a common pattern for taxa in the Galápagos (Parent et al., 2008). In addition, this work confirms the presence of two distinct clusters on San Cristóbal (Rassmann, 1996a; Rassmann et al., 1997; Steinfartz et al., 2009), with the use of far more extensive sampling than previous work. In pairwise $\mathrm{R}_{\mathrm{ST}}$ population comparisons, all populations differed in a statistically significant way $(P<0.01)$, though the divergence between some populations was fairly shallow (table 5). Though the magnitude of the $\mathrm{R}_{\mathrm{ST}}$ value may be reduced by the high levels of polymorphism demonstrated by the microsatellite loci used (Jost, 2008), this remains a useful measure of differentiation (Ryman and Leimar, 2009). Both the Punta Pitt and Pinta MUs demonstrated moderate to high $\left(\mathrm{R}_{\mathrm{ST}}>0.15\right.$; Frankham et al., 2002) divergence from all other MUs. The highest values are between Pinta and Punta Pitt $\left(\mathrm{R}_{\mathrm{ST}}=0.40\right)$ and, curiously, between Pinta and Genovesa $\left(\mathrm{R}_{\mathrm{ST}}=\right.$ 0.29 ), two of the more northerly islands that are not particularly geographically distant. This may hint at the influence of oceanic currents on gene flow within this species, and should be further investigated, as fine-scale oceanic data are lacking. The genetic distance between the San Cristóbal MUs $\left(\mathrm{R}_{\mathrm{ST}}=0.15\right)$ is also noteworthy, given the extreme geographical proximity of Downloaded from Brill.com04/26/2023 12:59:26PM via free access 
the two. Though the reasons for this divergence are presently unclear, geological data from San Cristóbal indicate a recent history of lava flows occurring in the area between these two populations (Geist et al., 1986). It is thus possible that volcanic activity could have caused habitat disturbance, resulting in a temporary separation of the $A$. cristatus range. The resultant divergence of these populations may have caused the development of reproductive barriers between them, which continue to facilitate the separation of these populations.

In terms of the mtDNA, Punta Pitt is again particularly outstanding, with values of $\theta_{\mathrm{ST}}>$ 0.9 when compared to almost all other MUs. Previous work (Steinfartz et al., 2009) has shown the haplotype found in the Punta Pitt MU to be the most distinctive of the archipelago, being seven mutational steps removed from any other known haplotype. The fact that this haplotype occurs in an entirely different clade than those harbored by animals from the neighboring MU (Loberia) on the same island, further underscores the apparent isolation between these two geographically proximate populations. Pinta, though outstanding in terms of microsatellite loci differentiation, is less so when considering the haplotype network, where it shares several haplotypes with neighboring islands Marchena and Genovesa (Steinfartz et al., 2009). This mismatch could be due to asymmetrical dispersal of males and females, resulting in the maternally inherited mitochondrial DNA reflecting a different connectivity pattern than the nuclear microsatellite loci (Rassmann et al., 1997).

This study finds a smaller number of clusters than previous work (20; Steinfartz et al., 2009), though the general pattern of clusters across the archipelago remains the same, e.g., Fernandina and Isabela show a close relationship, albeit with several admixed and shallowly diverged clusters in the earlier study, as opposed to the single cluster found in the present study. The discrepancy in cluster number between the two studies is in part due to differences in data selection. The former study included several small islands not considered in the present work; whereas in the current study, these data were pruned due to low sample size. Furthermore, island-specific sample sizes in general were far more varied in the earlier work, which could influence the results of the population structure analysis (Patterson et al., 2006). Though ideally we would utilize a sample size representative of the actual population size, sampling limitations and data deficiencies prevent us from doing so. Such limitations are unfortunately common in endangered species research. However, the sample size of $n>43$ individuals for all population clusters should be sufficient to reflect the genetic diversity within A. cristatus (Hale et al., 2012), and sampling bias is of smaller concern in well-differentiated populations (Shringarpure and Xing, 2014) such as those found here. Since populations from several small islands were excluded due to inadequate sample sizes, it is likely that some genetically distinct populations of A. cristatus are not represented. Therefore, it is necessary to collect and include samples from small islands such as Darwin, Wolf, and Pinzon for use in a similar future analysis, in order to fully assess the number of MUs across the archipelago.

There is a clear discrepancy between the subspecies currently used as units for conservation management (fig. 1) and the MUs delineated herein (fig. 2). When considering why the genetic units differ from the current taxonomy, it is appropriate to look at the information used for the taxonomic designations. The seven subspecies currently recognized are delineated on the basis of variation in external characters such as body size and coloration, scale morphometrics, and island biogeography (Bell, 1825; Eibl-Eibesfeldt, 1962). Although body size in A. cristatus is likely to have a genetic component, as shown for the common green iguana (Wikelski and Romero, 2003), environmental conditions also have a strong influence (Wikelski and Trillmich, 1997; Wikelski et al., 1997; Wikelski and Thom, 2000; Wikelski and Wrege, 2000; Wikelski, 2005). Further- 
more, coloration is highly variable across the archipelago, and may be related to diet, and not necessarily reflect evolutionary trajectories (Rassmann, 1996a). Therefore, the information upon which the current taxonomy was built is unlikely to accurately reflect the evolutionary history of this species.

\section{Effective population sizes}

We obtained consistent estimates from several methods for the Floreana/Española, Marchena, Loberia, and Punta Pitt MUs. For the Floreana/Española MU the estimates are somewhat surprising (201-286, obtained by two methods), since the $\mathrm{N}_{\mathrm{c}}$ for these islands is not overly small (Floreana $\mathrm{N}_{\mathrm{c}}=2000-16000$; Española $\mathrm{N}_{\mathrm{c}}=$ 1700-21 000). However, the wide range in census size estimates given by Wikelski and Nelson (2004) implies that they are particularly rough, and/or that the population sizes are quite variable, and thus it may be that the small $\mathrm{N}_{\mathrm{e}}$ estimates are genuinely reflecting a small population size. Results appear conclusive for both of the San Cristóbal MUs, where all methods produced consistent estimates. It seems reasonable to interpret these results as indicative of extremely small population sizes, both $<100$; indeed this is in keeping with the low $\mathrm{N}_{\mathrm{c}}$ estimates of Wikelski and Nelson (2004). The TEMPOFS method produced estimates for most MUs, and eight out of nine appear to be below the $\mathrm{N}_{\mathrm{e}} 1000$ threshold recommended for maintenance of evolutionary potential (Frankham et al., 2014). We were unable to obtain estimates using most methods, including TEMPOS-FS, for the Santiago MU. This MU had the smallest dataset (20 samples from 1991 and 27 from 2004) and it may be that this island is undersampled for the purposes of $\mathrm{N}_{\mathrm{e}}$ estimation.

The variation in estimates given by different methods may be because these methods do not estimate $\mathrm{N}_{\mathrm{e}}$ in the same generation, with single sample methods giving information about the parental generation of the animals sampled, and temporal methods estimating the harmonic mean of the $\mathrm{N}_{\mathrm{e}}$ between the two gen- erations sampled (Waples, 2005). In general, temporal methods are considered more powerful and can thus be expected to give more precise estimates with narrower CIs (Luikart et al., 2010). Indeed, we found this to be the case in the current study, though when estimates with a narrow CI from the LDNE method were obtained, they were much lower than those given by other estimators. If recent bottlenecks exist in populations, such as the one suspected on Marchena Island, which may be the result of El Niño induced crashes or recent volcanic activity (Steinfartz et al., 2007), this could downwardly bias these estimates (Waples, 2005) and might account for this discrepancy. Violation of the assumption of discrete generations, inherent in temporal estimation methods (Luikart et al., 1998), may be a more serious consideration. Amblyrhynchus cristatus females first breed at five years (Nelson et al., 2004) and as opposed to 12 years in males (Wikelski and Romero, 2003), though this may be earlier following El Niño related population crashes (Wikelski and Nelson, 2004), and "sneaker" mating strategies may afford some younger males breeding opportunities (Wikelski and Romero, 2003). For most islands, the temporal samples used were separated by 11-13 years, during which time a strong El Niño occurred in 1997 (Steinfartz et al., 2007), and thus these time periods are likely to span more than one generation, therefore reducing bias associated with violating the discrete generation assumption. For San Cristóbal, where sampling intervals are separated over 20 years, the bias resulting from overlapping generations is likely to be negligible (Waples and Yokota, 2007).

The small $\mathrm{N}_{\mathrm{e}}$ of the Marchena population may reflect natural events (Steinfartz et al., 2007), but this population should be carefully monitored to ensure that human-related threats are not enhancing the chances of population crashes. All other MUs with consistently small estimated population sizes include islands with permanent human settlements, with more severe anthropogenic threats. The human population 
on Floreana is relatively small, and most of the island is considered undisturbed (Watson et al., 2010), however invasive animals may be having a serious effect as a lack of juveniles has been reported (Cayot et al., 1994; Wikelski and Nelson, 2004). The risk on San Cristóbal is likely to be even higher, as this island is considered the most human-modified island in the archipelago
(Watson et al., 2010). Researchers have voiced concerns regarding the small size and lack of recruitment in San Cristóbal populations for over three decades (Laurie, 1983; Rassmann, 1996b; Wikelski and Nelson, 2004). Whether the apparent lack of juveniles is related to the presence of feral cats known to inhabit the immediate area of many colonies remains to be investigated,

Table 7. Prioritization of MUs in Amblyrhynchus cristatus from the Galápagos archipelago, Ecuador, in terms of conservation management and based on evaluation of multiple factors discussed throughout this paper. Census size estimates refer to those of Wikelski and Nelson (2004).

\begin{tabular}{|c|c|c|}
\hline Priority level & MU & Considerations \\
\hline \multirow[t]{3}{*}{ High } & Punta Pitt (San Cristóbal) & $\begin{array}{l}\text { Small } \mathrm{N}_{\mathrm{e}} \\
\text { Small census size estimates } \\
\text { Reproductively isolated from neighboring colonies } \\
\text { Presence of introduced predators } \\
\text { Low microsatellite heterozygosity } \\
\text { No mtDNA diversity } \\
\text { Outstanding genetic distinctiveness }\end{array}$ \\
\hline & Loberia (San Cristóbal) & $\begin{array}{l}\text { Small } \mathrm{N}_{\mathrm{e}} \\
\text { Small census size estimates } \\
\text { Reproductively isolated from neighboring colonies } \\
\text { Presence of introduced predators } \\
\text { Human encroachment } \\
\text { High risk of exposure to marine pollution }\end{array}$ \\
\hline & Floreana/Española & $\begin{array}{l}\text { Small } \mathrm{N}_{\mathrm{e}} \\
\text { Presence of introduced predators } \\
\text { Human encroachment }\end{array}$ \\
\hline \multirow[t]{5}{*}{ Moderate } & Santa Cruz & $\begin{array}{l}\text { Small } \mathrm{N}_{\mathrm{e}} \text { (may require confirmation) } \\
\text { Presence of introduced predators } \\
\text { Little mtDNA diversity } \\
\text { Introduced predators } \\
\text { Human encroachment } \\
\text { High risk of exposure to marine pollution }\end{array}$ \\
\hline & Marchena & $\begin{array}{l}\text { Small } \mathrm{N}_{\mathrm{e}} \\
\text { Evidence of genetic bottleneck (Steinfartz et al., 2007) }\end{array}$ \\
\hline & Pinta & $\begin{array}{l}\text { Small } \mathrm{N}_{\mathrm{e}} \\
\text { Relatively small census size estimates } \\
\text { Low heterozygosity } \\
\text { Outstanding genetic distinctiveness (microsatellites) }\end{array}$ \\
\hline & Santiago & $\begin{array}{l}\mathrm{N}_{\mathrm{e}} \text { unknown } \\
\text { Presence of introduced predators } \\
\text { Relatively small census size estimates } \\
\text { Additional data and sampling needed }\end{array}$ \\
\hline & Santa Fé & $\begin{array}{l}\text { Small } \mathrm{N}_{\mathrm{e}} \\
\text { Relatively small census size estimates } \\
\text { Recent losses through marine pollution }\end{array}$ \\
\hline \multirow[t]{2}{*}{ Low } & Genovesa & $\begin{array}{l}\mathrm{N}_{\mathrm{e}} \text { approaching level required to maintain evolutionary potential } \\
\text { Moderate census size estimates }\end{array}$ \\
\hline & Fernandina/Floreana & $\begin{array}{l}\text { Large } \mathrm{N}_{\mathrm{e}} \\
\text { Large census size estimates }\end{array}$ \\
\hline
\end{tabular}


but seems likely. In recent years, the Galápagos National Park authority has undertaken work to control feral cats around Punta Pitt. Though this is primarily intended to protect the local Redfooted Booby (Sula sula), it may also benefit $A$. cristatus, and indeed population size estimates increased between the 1991-1993 and 2011-2014 sampling intervals following eradication efforts (table 4).

\section{Conclusions and recommendations}

We identify 10 distinct population clusters of A. cristatus across the Galápagos archipelago, which should serve as management units for this species. Of these MUs, several appear alarmingly small and should be carefully monitored (see table 7 for prioritized recommendations). On the grounds of its genetic distinctiveness, apparent reproductive isolation, small population size, genetic paucity, and exposure to anthropogenic threats, the Punta Pitt MU on San Cristóbal should be the single highest priority for management within this species. The striking reproductive isolation between this MU and the geographically proximate Loberia population calls for a more in-depth taxonomic evaluation. The lack of $A$. cristatus recruitment noted by Cayot et al. (1994) on Isabela, Floreana, Santa Cruz, and San Cristóbal is unlikely to have improved given that many of the anthropogenic threats are expected to intensify with a growing human population. However, we simply do not have the data to fully understand the threats and conservation status of the iguanas across most of the archipelago as recent surveys are sorely lacking. This poses a problem for those tasked with undertaking conservation assessments and prioritizing management actions. Though the present work provides estimates of genetic effective population size, contemporary census size estimates are still urgently required. $\mathrm{N}_{\mathrm{e}}$ estimates allow for prioritized protection of genetic diversity within a species, but consensus size estimates are necessary for directly monitoring the trajectory of populations. Our deficiency in knowledge regarding the size and health of A. cristatus populations may seriously impede us from recognizing emergent threats and affording protection against known threats. Without adequate protection, these threats may depress populations to critically small levels where they lack the resilience to withstand environmental changes.

The recognition and prioritization of MUs outlined herein allows for a shift of conservation efforts, moving the focus from questionable taxonomic entities towards more biologically meaningful units which correspond to the population boundaries and distribution of genetic diversity in this species. The use of MUs for management planning will allow attention to be directed toward locations and populations most at risk, and should improve efforts to monitor the impact of threats on key populations. Such an approach bypasses the issue of taxonomic uncertainty to facilitate the protection of vital genetic diversity in this vulnerable species.

Acknowledgements. This publication is contribution number 2112 of the Charles Darwin Foundation for the Galápagos Islands. We are grateful to: the Galápagos National Park authority for research permission (permit number PC22-14); to Lydia Unsworth, Carolina Garcia-Parra, Maryuri Yépez, Jeffreys Málaga, Lorea Cardas, María D. Astudillo, Timm Reinhardt, Lenin Cruz and Diego Toninho for field assistance and transportation; to Solanda Rea for invaluable help with paperwork; to Elke Hippauf and Meike Kondermann for help with labwork; and to Alejandro Ibáñez Ricomá for translation. We thank Stesha Pasachnik, Tandora Grant, Jonathon Marshall and two anonymous reviewers for their improvement of the manuscript. This work was supported by generous grants from The Swiss Friends of the Galápagos, The Galápagos Conservation Trust, and the National Geographic Society.

\section{References}

Aguilera, W.T., Málaga, J., Gibbs, J.P. (2015): Conservation: giant tortoises hatch on Galápagos island. Nature 517: 271.

Alava, J.J., Palomera, C., Bendell, L., Ross, P.S. (2014): Pollution as an emerging threat for the conservation of the Galápagos Marine Reserve: environmental impacts and management perspectives. In: The Galápagos Marine Reserve: a Dynamic Socio-Ecological System, p. 247283. Vinueza, L., Denkinger, J., Eds, Springer International Publishing, New York. 
Balloux, F. (2004): Heterozygote excess in small populations and the heterozygote-excess effective population size. Evolution 58: 1891-1900.

Bell, T. (1825): On a new genus of Iguanidae. J. Zool. 2: 204-207.

Bentzen, P. (1998): Seeking evidence of local stock structure using molecular genetic methods. In: The Implications of Localized Fishery Stock, p. 20-30. Hunt von Herbing, I., Kornfield, I., Tupper, M., Wilson, J., Eds, Natural Resource, Agriculture, and Engineering Service, Ithaca, New York.

Berger, S., Wikelski, M., Romero, L.M., Kalko, E.K., Rödl, T. (2007): Behavioral and physiological adjustments to new predators in an endemic island species, the Galápagos marine iguana. Horm. Behav. 52: 653-663.

Berry, O., Tocher, M.D., Sarre, S.D. (2004): Can assignment tests measure dispersal? Mol. Ecol. 13: 551-561.

Berthier, P., Beaumont, M.A., Cornuet, J.M., Luikart, G. (2002): Likelihood-based estimation of the effective population size using temporal changes in allele frequencies: a genealogical approach. Genetics 160: 741751.

Broquet, T., Petit, E.J. (2009): Molecular estimation of dispersal for ecology and population genetics. Annu. Rev. Ecol. Evol. Syst. 40: 193-216.

Campbell, K., Donlan, C.J., Cruz, F., Carrion, V. (2004): Eradication of feral goats Capra hircus from Pinta Island, Galápagos, Ecuador. Oryx 38: 328-333.

Carrion, V., Donlan, C.J., Campbell, K., Lavoie, C., Cruz, F. (2007): Feral donkey (Equus asinus) eradications in the Galápagos. Biodivers. Conserve. 16: 437-445.

Cayot, L.J., Rassmann, K., Trillmich, F. (1994): Are marine iguanas endangered on islands with introduced predators? Noticias de Galápagos 53: 13-15.

Chikhi, L., Sousa, V.C., Luisi, P., Goossens, B., Beaumont, M.A. (2010): The confounding effects of population structure, genetic diversity, and the sampling scheme on the detection and quantification of population size changes. Genetics 186: 983-995.

Ciofi, C., Beaumont, M.A., Swingland, I.R., Bruford, M.W. (1999): Genetic divergence and units for conservation in the Komodo dragon Varanus komodoensis. Proc. R. Soc. B 266: 2269-2274.

Cunha, H.A., Medeiros, B.V., Barbosa, L.A., Cremer, M.J., Marigo, J., Lailson-Brito, J., Azevedo, A.F., SoléCava, A.M. (2014): Population structure of the endangered Franciscana dolphin (Pontoporia blainvillei): reassessing management units. PLoS ONE 9: e85633. DOI:10.1371/journal.pone.0085633.

Do, C., Waples, R.S., Peel, D., Macbeth, G., Tillett, B.J., Ovenden, J.R. (2014): NeEstimator V2: reimplementation of software for the estimation of contemporary effective population size $\left(\mathrm{N}_{\mathrm{e}}\right)$ from genetic data. Mol. Ecol. Res. 14: 209-214.

Earl, D.A., vonHoldt, B.M. (2012): STRUCTURE HARVESTER: a website and program for visualizing STRUCTURE output and implementing the Evanno method. Conserv. Genet. Resour. 4: 359-361.
Eibl-Eibesfeldt, I. (1962): Neue Unterarten der Meerechse, Amblyrhynchus cristatus, nebst weiteren Angaben zur Biologie der Art. Senckenbergiana Biologica 43: 177199.

Evanno, G., Regnaut, S., Goudet, J. (2005): Detecting the number of clusters of individuals using the software STRUCTURE: a simulation study. Mol. Ecol. 14: 26112620.

Excoffier, L., Lischer, H.E. (2010): Arlequin suite ver 3.5: a new series of programs to perform population genetics analyses under Linux and Windows. Mol. Ecol. Res. 10: 564-567.

Frankham, R. (2005): Genetics and extinction. Biol. Cons. 126: $131-140$

Frankham, R. (2010): Challenges and opportunities of genetic approaches to biological conservation. Biol. Cons. 143: 1919-1927.

Frankham, R., Ballou, J.D., Briscoe, D.A. (2002): Introduction to Conservation Genetics. Cambridge University Press.

Frankham, R., Bradshaw, C.J., Brook, B.W. (2014): Genetics in conservation management: revised recommendations for the 50/500 rules, Red List criteria and population viability analyses. Biol. Cons. 170: 56-63.

Fraser, D.J., Bernatchez, L. (2001): Adaptive evolutionary conservation: towards a unified concept for defining conservation units. Mol. Ecol. 10: 2741-2752.

Geist, D.J., McBirney, A.R., Duncan, R.A. (1986): Geology and petrogenesis of lavas from San Cristóbal Island, Galápagos Archipelago. Geol. Soc. Am. Bull. 97: 555566.

Geist, D.J., Snell, H., Snell, H., Goddard, C., Kurz, M.D. (2014): A paleogeographic model of the Galápagos Islands and biogeog raphical and evolutionary implications. In: The Galápagos: a Natural Laboratory for the Earth Sciences, p. 145-166. Harpp, K.S., Mittelstaedt, E., d'Ozouville, N., Graham, D.W., Eds, American Geophysical Union, Washington, D.C.

González-Suárez, M., Flatz, R., Aurioles-Gamboa, D., Hedrick, P., Gerber, L. (2009): Isolation by distance among California sea lion populations in México: redefining management stocks. Mol. Ecol. 18: 1088-1099.

Hale, M.L., Burg, T.M., Steeves, T.E. (2012): Sampling for microsatellite-based population genetic studies: 25 to 30 individuals per population is enough to accurately estimate allele frequencies. PloS ONE 7: e45170. DOI:10.1371/journal.pone.0045170.

Hanley, T., Caccone, A. (2005): Development of primers to characterize the mitochondrial control region of Galápagos land and marine iguanas (Conolophus and Amblyrhynchus). Mol. Ecol. Notes 5: 599-601.

Hastings, A. (1993): Complex interactions between dispersal and dynamics - lessons from coupled logistic equations. Ecology 74: 1362-1372.

Jakobsson, M., Rosenberg, N.A. (2007): CLUMPP: a cluster matching and permutation program for dealing with label switching and multimodality in analysis of population structure. Bioinformatics 23: 1801-1806.

Jorde, P.E., Ryman, N. (2007): Unbiased estimator for genetic drift and effective population size. Genetics 177 : 927-935. 
Jost, L. (2008): GST and its relatives do not measure differentiation. Mol. Ecol. 17: 4015-4026.

Konecny, M.J. (1983): Behavioral ecology of feral house cats in the Galápagos Islands, Ecuador. Ph.D. Dissertation, University of Florida, Gainesville, Florida, USA. $136 \mathrm{pp}$.

Kruuk, H., Snell, H. (1981): Prey selection by feral dogs from a population of marine iguanas (Amblyrhynchus cristatus). J. Appl. Ecol. 18: 197-204.

Lande, R. (1998): Risk of population extinction from fixation of deleterious and reverse mutations. Genetica 102: 21-27.

Laurie, W.A. (1983): Marine iguanas in Galápagos. Oryx 17: $18-25$.

Laurie, W.A., Brown, D. (1990): Population biology of marine iguanas (Amblyrhynchus cristatus). II. Changes in annual survival rates and the effects of size, sex, age, and fecundity in a population crash. J. Anim. Ecol. 59: 529-544.

Lowe, W.H., Allendorf, F.W. (2010): What can genetics tell us about population connectivity? Mol. Ecol. 19: 30383051 .

Luikart, G., Ryman, N., Tallmon, D.A., Schwartz, M.K., Allendorf, F.W. (2010): Estimation of census and effective population sizes: the increasing usefulness of DNAbased approaches. Conserv. Genet. 11: 355-373.

Luikart, G., Sherwin, W., Steele, B., Allendorf, F.W. (1998): Usefulness of molecular markers for detecting population bottlenecks via monitoring genetic change. Mol. Ecol. 7: 963-974.

Mace, G.M. (2004): The role of taxonomy in species conservation. Phil. Trans. R. Soc. B 359: 711-719.

Manel, S., Gaggiotti, O.E., Waples, S. (2005): Assignment methods: matching biological questions with appropriate techniques. Trends Ecol. Evol. 20: 136-142.

McNeely, J.A., Miller, K.R., Reid, W.V., Mittermeier, R.A., Werner, T.B. (1990): Conserving the World's Biological Diversity. World Resources Institute, IUCN, World Bank, WWF-US, and Conservation International, Washington, D.C., USA and Gland, Switzerland.

Moritz, C. (1994): Defining "evolutionarily significant units" for conservation. Trends Ecol. Evol. 9: 373-375.

Nei, M. (1987): Molecular Evolutionary Genetics. Columbia University Press, New York.

Nelson, K., Snell, H., Wikelski, M. (2004): Amblyrhynchus cristatus. The IUCN Red List of threatened species. Version 2014.3. Available at http://www.iucnredlist.org/ details/summary/1086/0 [accessed 02 September 2014].

Nomura, T. (2008): Estimation of effective number of breeders from molecular coancestry of single cohort sample. Evol. Appl. 1: 462-474.

Oliveira, L.R., Loizaga De Castro, R., Cárdenas-Alayza, S., Bonatto, S.L. (2012): Conservation genetics of South American aquatic mammals: an overview of gene diversity, population structure, phylogeography, non-invasive methods, and forensics. Mammal Rev. 42: 275-303.

Paetkau, D., Waits, L.P., Clarkson, P.L., Craighead, L., Strobeck, C. (1997): An empirical evaluation of genetic distance statistics using microsatellite data from bear (Ursidae) populations. Genetics 147: 1943-1957.
Paetkau, D., Slade, R., Burdens, M., Estoup, A. (2004): Genetic assignment methods for the direct, real-time estimation of migration rate: a simulation-based exploration of accuracy and power. Mol. Ecol. 13: 55-65.

Palsbøll, P.J., Berube, M., Allendorf, F.W. (2007): Identification of management units using population genetic data. Trends Ecol. Evol. 22: 11-16.

Parent, C.E., Caccone, A., Petren, K. (2008): Colonization and diversification of Galápagos terrestrial fauna: a phylogenetic and biogeographical synthesis. Phil. Trans. R. Soc. B 363: 3347-3361.

Pasachnik, S.A., Echternacht, A.C., Fitzpatrick, B.M. (2011): Population genetics of the Honduran spinytailed iguana Ctenosaura melanosterna: implications for conservation and management. Endanger. Species Res. 14: 113-126.

Patterson, N., Price, A.L., Reich, D. (2006): Population structure and eigenanalysis. PLoS Genetics 2: e190. DOI:10.1371/journal.pgen.0020190.

Peakall, R., Smouse, P.E. (2012): GenAlEx 6.5: genetic analysis in Excel. Population genetic software for teaching and research - an update. Bioinformatics 28: 2537 2539.

Peel, D., Ovenden, J., Peel, S. (2004): NeEstimator: software for estimating effective population size, Version 1.3. Queensland Government, Department of Primary Industries and Fisheries, Australia.

Piry, S., Alapetite, A., Cornuet, J.M., Paetkau, D., Baudouin, L., Estoup, A. (2004): GENECLASS2: a software for genetic assignment and first-generation migrant detection. J. Hered. 95: 536-539.

Pritchard, J.K., Stephens, M., Donnelly, P. (2000): Inference of population structure using multilocus genotype data. Genetics 155: 945-959.

Rannala, B., Mountain, J.L. (1997): Detecting immigration by using multilocus genotypes. Proc. Natl. Acad. Sci. U.S.A. 94: 9197-9221.

Rassmann, K. (1996a): The molecular evolution of the Galápagos iguanas (Amblyrhynchus cristatus Bell, Conolophus subcristatus Gray, and C. pallidus Heller). Ph.D. Dissertation, Universitat Bielefeld, Bielefeld, Germany. 187 pp.

Rassmann, K. (1996b): Molecular genetics and conservation in the Galápagos. Bull. Mar. Sci. 56: 670-675.

Rassmann, K. (1997): Evolutionary age of the Galápagos iguanas predates the age of the present Galápagos Islands. Mol. Phylogenet. Evol. 7: 158-172.

Rassmann, K., Tautz, D., Trillmich, F., Gliddon, C. (1997): The microevolution of the Galápagos marine iguana Amblyrhynchus cristatus assessed by nuclear and mitochondrial genetic analyses. Mol. Ecol. 6: 437-452.

Rosenberg, N.A. (2004): DISTRUCT: a program for the graphical display of population structure. Mol. Ecol. Notes 4: 137-138.

Ryman, N., Leimar, O. (2009): GST is still a useful measure of genetic differentiation - a comment on Jost's D. Mol. Ecol. 18: 2084-2087.

Shringarpure, S., Xing, E.P. (2014): Effects of sample selection bias on the accuracy of population structure and ancestry inference. G3 (Bethesda) 4: 901-911. DOI: $10.1534 / \mathrm{g} 3.113 .007633$. 
Slatkin, M. (1995): A measure of population subdivision based on microsatellite allele frequencies. Genetics 139: 457-462.

Steinfartz, S., Caccone, A. (2006): A set of highly discriminating microsatellite loci for the Galápagos marine iguana Amblyrhynchus cristatus. Mol. Ecol. Notes 6: 927-929.

Steinfartz, S., Glaberman, S., Lanterbecq, D., Marquez, C., Rassmann, K., Caccone, A. (2007): Genetic impact of a severe El Niño event on Galápagos Marine Iguanas (Amblyrhynchus cristatus). PloS ONE 2: e1285. DOI:10.1371/journal.pone.0001285.

Steinfartz, S., Glaberman, S., Lanterbecq, D., Russello, M.A., Rosa, S., Hanley, T.C., Marquez, C., Snell, H.L., Snell, H.M., Gentile, G. et al. (2009): Progressive colonization and restricted gene flow shape islanddependent population structure in Galápagos Marine Iguanas (Amblyrhynchus cristatus). BMC Evol. Biol. 9: 297. DOI:10.1186/1471-2148-9-297.

Timmermann, A., Oberhuber, J., Bacher, A., Esch, M., Latif, M., Roeckner, E. (1999): Increased El Niño frequency in a climate model forced by future greenhouse warming. Nature 398: 694-697.

Van Oosterhout, C., Hutchinson, W.F., Wills, D.P., Shipley, P. (2004): MICRO-CHECKER: software for identifying and correcting genotyping errors in microsatellite data. Mol. Ecol. Notes 4: 535-538.

Wallace, B.P., DiMatteo, A.D., Hurley, B.J., Finkbeiner, E.M., Bolten, A.B., Chaloupka, M.Y., Hutchinson, B.J., Abreu-Grobois, F.A., Amorocho, D., Bjorndal, K.A. et al. (2010): Regional management units for marine turtles: a novel framework for prioritizing conservation and research across multiple scales. PLoS ONE 5 (12): e15465. DOI:10.1371/journal.pone.0015465.

Waples, R.S. (2005): Genetic estimates of contemporary effective population size: to what time periods do the estimates apply? Molecular Ecology 14: 3335-3352.

Waples, R.S., Do, C. (2008): LDNE: a program for estimating effective population size from data on linkage disequilibrium. Mol. Ecol. Res. 8: 753-756.
Waples, R.S., Yokota, M. (2007): Temporal estimates of effective population size in species with overlapping generations. Genetics 175: 219-233.

Watson, J., Trueman, M., Tufet, M., Henderson, S., Atkinson, R. (2010): Mapping terrestrial anthropogenic degradation on the inhabited islands of the Galápagos Archipelago. Oryx 44: 79-82.

Wikelski, M. (2005): Evolution of body size in Galápagos Marine Iguanas. Proc. R. Soc. B 272: 1985-1993.

Wikelski, M., Carbone, C., Trillmich, F. (1996): Lekking in marine iguanas: female grouping and male reproductive strategies. Anim. Behav. 52: 581-596.

Wikelski, M., Carrillo, V., Trillmich, F. (1997): Energy limits to body size in a grazing reptile, the Galápagos marine iguana. Ecology 78: 2204-2217.

Wikelski, M., Nelson, K. (2004): Conservation of Galápagos Marine Iguanas (Amblyrhynchus cristatus). Iguana 11: 191-197.

Wikelski, M., Romero, L.M. (2003): Body size, performance and fitness in Galápagos Marine Iguanas. Integr. Comp. Biol. 43: 376-386.

Wikelski, M., Thom, C. (2000): Marine iguanas shrink to survive El Niño. Nature 403: 37-38.

Wikelski, M., Trillmich, F. (1997): Body size and sexual size dimorphism in marine iguanas fluctuate as a result of opposing natural and sexual selection: an island comparison. Evolution 51: 922-936.

Wikelski, M., Wong, V., Chevalier, B., Rattenborg, N., Snell, H.L. (2002): Galápagos Islands: marine iguanas die from trace oil pollution. Nature 417: 607-608.

Wikelski, M., Wrege, P.H. (2000): Niche expansion, body size, and survival in Galápagos Marine Iguanas. Oecologia 124: 107-115.

Submitted: January 7, 2016. Final revision received: January 29, 2016. Accepted: January 29, 2016.

Associate Editor: Jonathon Marshall. 